\title{
15 METU SIFILIO DIAGNOSTIKOS IR GYDYMO PATIRTIS DVIEJUOSE LIETUVOS CENTRUOSE
}

\author{
Tadas Raudonis ${ }^{1}$, Tatjana Orlovskytè ${ }^{1,2}$, Algirdas Šumila ${ }^{2}$, Aldona Kajutytė ${ }^{3}$, \\ Genovaitė Lapinskaité2, Matilda Bylaitė-Bučinskienè $\dot{1}^{1,2}$
}

\section{${ }^{1}$ Vilniaus universiteto Medicinos fakultetas, ${ }^{2}$ Vilniaus universiteto Dermatovenerologijos centras, ${ }^{3}$ Respublikine Klaipédos ligoniné}

Raktažodžiai: sifilis, kietasis šankeris, RPR, TPHA, ŽIV, benzatino benzilpenicilinas, doksiciklinas.
Santrauka
Sifilis - sisteminė liga, kuriai būdingas platus kli- nikinių pasireiškimų spektras, todèl su juo susidur- ti gali visų specialybių gydytojai. Pagal sergamumą sifiliu Lietuva yra viena iš pirmaujančiu šalių Eu- ropos Sajungoje. Šiame tyrime susisteminti per 15 metų sukaupti duomenys dviejuose Lietuvos der- matovenerologijos centruose - Vilniaus universiteto Dermatovenerologijos centre (DVC) ir Respubliki- nès Klaipėdos ligoninès Odos ir venerinių ligų poli- klinikoje (RKL).
Tikslai: nustatyti bei ịvertinti sifilio susirgimų skai- čių bei dinamiką DVC ir RKL 15 m. laikotarpiu, ly- čių pasiskirstymą, berimo elementus, diagnostiką, gydymą bei jo efektyvumą.
Medžiaga ir metodai: atlikta retrospektyvinè sifilio registracijos žurnalų bei ambulatorinių kortelių ana- lizè. I galutinę detalią analizę įtrauktos 1245 pacien- tu ambulatorinès kortelès: 793 pacientai iš DVC ir 452 iš RKL. Duomenų analizė atlikta SPSS, patiki- mumas skaičiuotas naudojant ANOVA, Fisher ir chi kvadrato testus.
Rezultatai: 2000-2003 m. laikotarpiu DVC ir RKL užregistruotas 691 (56 proc.) sifilio atvejis, 2004- 2014 m. - 554 (44 proc.) atvejai. Moterys sudarè 49 proc. (610) visų pacientų, jų amžiaus vidurkis - $29,5 \pm 11,3 \mathrm{~m}$., vyru $-34,3 \pm 12,3 \mathrm{~m} .(\mathrm{p}<0,001)$, metų eigoje jis reikšmingai nekito. Tarp mieste gy- venusių pacientų dirbantys vyrai sudare 55 proc. (222), bedarbès moterys -52 proc. $(186)(\mathrm{p}=0,050)$. Pirminis sifilis diagnozuotas 14 proc. (173) pacien- tuc, antrinis -34 proc. (427), ankstyvas latentinis -

45 proc. (561). Bẻrimo elementai apžiūros metu nustatyti 53 proc. (660) pacientų. Papulès stebètos 55 proc. (364) pacientų, erozijos - 39 proc. (254), kietasis šankeris - 33 proc. (220). Nustatyta, kad pirminiam ir ankstyvam latentiniam sifiliui būdingas žemas ir vidutinis RPR titras, o antriniam - išskirtinai aukštas (69 proc. (296). 6 proc. (70) pacientu RPR tyrimas buvo neigiamas. 4 ir daugiau RPR tyrimų atlikta 19 proc. (76) DVC ir 48 proc. (90) RKL pacientu $(\mathrm{p}<0,001)$. Tamsaus lauko mikroskopija atlikta 19 proc. (151) DVC ir 41 proc. (186) RKL pacientų $(\mathrm{p}<0,001)$. ŽIV antikūnų tyrimas atliktas 61 proc. (485) DVC ir 10 proc. (47) RKL pacientuc $(\mathrm{p}<0,001) .37$ proc. (462) pacientu gydyti benzatino benzilpenicilinu, vidutiniškai skiriant 3 injekcijas po $2,4 \mathrm{mln}$. VV/sav. Doksiciklinu gydyta 7 proc. (90) pacientų, vidutiniškai skiriant po $200 \mathrm{mg}$, iš viso - 23 dienas $(4,7 \pm 1,2 \mathrm{~g}$ suminè dozè). Laikas iki teigiamo serologinio atsako, lyginant abu medikamentus, reikšmingai nesiskyre $(5,09[3,94 ; 6,25]$ vs. $4,85[2,86 ; 6,85]$ mèn.). 7,3 proc. (91) pacientų nepasiekè teigiamo serologinio atsako (7 proc. (55) DVC vs. 8 proc. (36) RKL ( $\mathrm{p}=0,951)$.

Išvados. Per $15 \mathrm{~m}$. DVC ir RKL registruojamų sifilio atvejų skaičius sumažèjo beveik 10 kartų, tačiau sergamumas sifiliu vis tiek išlieka vienas didžiausių Europoje. Dažniausiai diagnozuotas ankstyvas latentinis ir antrinis sifilis. Pasiskirstymas tarp lyčių buvo beveik vienodas, tačiau sergantys sifiliu vyrai buvo 5 metais vyresni už moteris. Apžiūros metu bẻrimai nustatyti tik pusei pacientų. Mažiau nei pusè pacientų buvo tirti dèl ŽIV. Gydymas doksiciklinu ir benzatino benzilpenicilinu buvo vienodai efektyvūs. Tik trečdaliui pacientų po gydymo atliktas rekomenduojamas RPR tyrimų skaičius. 


\section{Ivadas}

Sifilis - sisteminè, dažniausiai lytiškai plintanti liga, kurią sukelia Treponema pallidum. Jai būdingas platus klinikinių pasireiškimų spektras bei ịvairios trukmès besimptomiai periodai $[1,2]$. Infekcijos šaltinis - sifiliu sergantys asmenys. Dèl savo simptomų ịvairovès ir panašumo ị kitas ligas sifilis literatūroje dažnai vadinamas „didžiuoju pamègdžiotoju“ (angl. the great imitator) [3]. Todèl su juo susidurti gali bet kurios specialybès gydytojas. Klaidinanti klinika bei savaime praeinantys ir dažnai nepastebimi simptomai labai apsunkina ligos diagnostiką $[1,4]$. Pagal ligos išraišką sifilis skirstomas ị ankstyvą: pirminị, antrinị, latentinị; ir vèlyvą: latentinị bei tretinį (gumų stadijos, kardiovaskulinị bei neurosifilį). Jei pasireiškia anksti, neurosifilis gali būti priskirtas antriniam sifiliui [5]. Vèlyvas sifilis, pagal Europos ligų prevencijos ir kontrolès centrą (ECDC), diagnozuojamas, kai trunka ilgiau nei $1 \mathrm{~m}$., o pagal Pasaulio sveikatos organizaciją (PSO) - ilgiau nei $2 \mathrm{~m}$. [5,6]. Lietuvoje vadovaujamasi PSO apibrěžimu. Kasmet pasaulyje diagnozuojama per 10 milijonų naujų ligos atvejų [7]. 2000 - 2004 m. naujų sifilio atvejų skaičius Lietuvoje ryškiai mažèjo, o nuo $2005 \mathrm{~m}$. stebimas nežymus svyravimas su mažejjimo tendencija [8]. Tačiau 2013 m. Lietuvoje sergamumas sifiliu siekè 9,1 atvejo šimtui tūkstančių gyventojų $[8,9]$. ES šis rodiklis didesnis tik Rumunijoje [10]. Taip pat vis dažniau susiduriama su pacientų gydymo režimo nesilaikymo (angl. non-compliance) bei neatvykimo ligos kontrolès problemomis [11]. Dèl šių priežasčių nusprendème ivvertinti turimus duomenis apie sifiliu sergančius pacientus dviejuose dermatovenerologijos centruose Lietuvoje - Vilniaus universiteto Dermatovenerologijos centre (DVC) ir Respublikinès Klaipėdos ligoninès Odos ir venerinių ligų poliklinikoje (RKL).

Darbo tikslai: nustatyti susirgimų skaičių ir jo kitimą DVC ir RKL 2000-2014 m., įvertinti lyčių pasiskirstymą, pasireiškusius bèrimo elementus ir jų dažniausias lokalizacijas bei lydinčius simptomus. Taip pat ịvertinti taikytus sifilio diagnostinius metodus, pacientų ištyrimo kokybę, taikytą gydymą, jo efektyvumą bei trukmę iki teigiamo serologinio atsako.

\section{Tyrimo medžiaga ir metodai}

Atlikta retrospektyviné 2000-2014 m. sifilio registracijos žurnalų bei ambulatorinių kortelių analizè. Per 15 stebejjimo $\mathrm{m}$. DVC buvo užregistruota 852 , RKL - 667 sifilio atvejai. I detalią analizę įtrauktos 1245 ambulatorinès kortelès: 793 pacientai iš DVC ir 452 iš RKL, kitu pacientų ambulatorinès kortelès buvo nekokybiškai užpildytos, arba jų nepavyko rasti archyve. Vertinti demografiniai, epidemiologiniai, klinikiniai bei laboratoriniai rodikliai. Taip pat telefonu susisiekta su 10 pacientų, 3 metų laikotarpiu gydytų DVC ir neatvykusių gydymo kontrolès. Duomenų analizè atlikta SPSS programa, patikimumas skaičiuotas naudojant ANOVA, Fisher ir chi kvadrato testus.

\section{Rezultatai}

Per 15 metų sifilis buvo diagnozuotas 1245 pacientams, iš kuriu 610 (49 proc.) buvo moterys. Moterų amžiaus vidurkis $-29,5 \pm 11,3 \mathrm{~m}$., vyru $-34,3 \pm 12,3 \mathrm{~m}$. $(\mathrm{p}<0,001)$. Taigi pastarieji buvo vidutiniškai 5 metais vyresni už moteris. Metų eigoje amžiaus vidurkis reikšmingai nekito ir tarp centrų nesiskyrè. 2000-2003 m. diagnozuoti atvejai sudarè 56 proc. (691) visų pacientu, o 2004-2014 m. - 44 proc. (554). Daugiausia susirgimų nustatyta 2000 (320), mažiausiai - 2014 metais (36). Vyrai nurode daugiau lytiniu partnerių paskutinių 24 mèn. laikotarpiu $(1,57[1,45 ; 1,69]$ vs. $1,38[1,28 ; 1,48])$, iš jų ištirta tik 32 proc. (200) (DVC - 29 proc., $R K L-36$ proc.) $(\mathrm{p}=0,213)$. Iš moterų nurodytų lytinių partnerių ištirta 50 proc. (307) (DVC - 56 proc., RKL -41 proc.) $(\mathrm{p}=0,001)$. Tarp kaime gyvenančių pacientu (39 proc. (485), 63 proc. moterų ir 67 proc. $(\mathrm{p}=0,393)$ vyrų buvo bedarbiai, tačiau tarp gyvenusių mieste sifiliu dažniau užsikretė dirbantys vyrai (55 proc.) ir bedarbès moterys (52 proc.) $(\mathrm{p}=0,050) .4$ proc. (47) visų pacientų sifiliu užsikrète pakartotinai. Moterys ị DVC dažniausiai kreipèsi su gydytojo akušerio - ginekologo siuntimu (45 proc. (173), tuo tarpu i RKL - be gydytojo siuntimo (29 proc. (66) ( $\mathrm{p}<0,001)$, kaip ir didžioji dalis vyrų abejose klinikose (atitinkamai 30 proc. (121) ir 39 proc. (88). 34 proc. (209) moterų sifilis nustatytas néštumo profilaktinių tyrimų metu: DVC -37 proc. (143), RKL -29 proc. $(65)(\mathrm{p}=0,065)$.

Pirminis sifilis (14 proc. (173) buvo diagnozuojamas ganètinai retai, palyginus su antriniu (34 proc. (427) ir ankstyvuoju latentiniu (45 proc. (561). Kitos formos (igimtas bei vèlyvas) sudare mažą susirgimų skaičių (7 proc. (84), DVC diagnozuotas 1 gumos stadijos ir 1 kardiovaskulinio sifilio atvejis, igimtas sifilis diagnozuotas 9 naujagimiams, paskutinis atvejis $-2009 \mathrm{~m}$. Moterims dažniausiai diagnozuotas ankstyvas latentinis (55 proc. (335) ir antrinis (35 proc. (213) sifilis. Tuo tarpu vyrams net keturis kartus dažniau nei moterims nustatytas pirminis sifilis (22 proc. (139) vs. 7 proc. $(34)(p<0,001)(1$ pav.). Taip pat ryškiai skyrèsi vyrų sifilio formų pasiskirstymas tarp DVC ir RKL: pirminis sifilis nustatytas atitinkamai 24 (99) ir 18 proc. (40) vyrų, antrinis - 30 (122) ir 41 proc. (92), o ankstyvas latentinis - 33 (136) ir 40 proc. (90) pacientu $(\mathrm{p}<0,001)$.

Bèrimo elementai apžiūros metu nustatyti 53 proc. (660) pacientų. Dažniausiai stebètos papulès, erozijos ir kietasis šankeris (1 lentelè), be to, daugumai jų pasireiškè daugiau nei vienos rūšies bėrimai. Kietasis šankeris (2 
pav.) 65 proc. (31) moterų nustatytas didžiujų ir 25 proc. (12) - mažujų lytinių lūpų srityse, pavieniais atvejais rastas makšties gleivinèje (3) bei išangès (2) srityje. Tuo tarpu 49 proc. (86) vyrų jis nustatytas apyvarpeje, 26 proc. (46) ties varpos galvute ir 21 proc. (37) - varpos odoje, pavieniais atvejais šankeris rastas sẻklidžių (2), išangès (2), lūpų (2) ir burnos gleivinès (1) srityse. Antrinis sifilis nustatytas 30 proc. (66) pacientu su kietuoju šankeriu. Plokščiosios kondilomos (3 pav.) 88 proc. (60) moterų aptiktos apie išangę, 49 proc. (33) - didžiujų ir 47 proc. (32) - mažujų lytinių lūpų srityse, o vyrams - 85 proc. (29) apie išangę, 35 proc. (12) varpos odoje. Papulès (4 pav.) pacientams nustatytos visose kūno srityse. Detali bèrimo lokalizaciju analizè pateikiama 2 lenteleje.

Taip pat vertinti ir kiti pacientams pasireiškę simptomai. Limfadenopatija nustatyta 80 proc. (480) pacientu, kuriems diagnozuotas pirminis ir antrinis sifilis. Sergant antriniu sifiliu, reikšmingai dažniau pasitaike tonzilitas 28 proc. (118), alopecija - 20 proc. (85), išskyrų iš lytinių organų pagausèjimas -26 proc. $(111)(\mathrm{p}<0.001)$. Neurosifiliu sirgusiems pacientams (32) dažnai nustatyta amnezija, delyras - 71 proc. (24), galvos skausmai - 50 proc. (16), ataksija - 41 proc. (14), psichikos sutrikimas - 32 proc. (11) $(\mathrm{p}<0,001)$.

Nustatytas RPR titras sugrupuotas į 3 kategorijas: žemas $(1: 1-1: 4)$, vidutinis $(1: 8-1: 32)$ ir aukštas $(1: 64$ ir $>$ ). Pastebèta, kad pirminiam ir ankstyvam latentiniam sifiliui būdingas žemas ir vidutinis RPR titras, o antriniam - išskirtinai aukštas (69 proc. (296) (5 pav.). Pažymétina, kad 6 proc. (70) pacientų (17 pacientu - pirminio, 2 - antrinio, 49 ankstyvo ir 2 vèlyvo latentinio sifilio metu) nustatytas neigiamas RPR titras. Tik 28 proc. (167) pacientų atlikti keturi ar daugiau RPR tyrimų

1 lentelè. Pacientų, kuriems diagnozuotas sifilis (Dermatovenerologijos centre (DVC) ir Respublikinèje Klaipėdos ligoninejje (RKL) bèrimo elementų pasireiškimo dažnis $(\mathrm{N}=1245)$

\begin{tabular}{|l|c|c|}
\hline \multirow{2}{*}{\multicolumn{1}{|c|}{ Bèrimo elementai }} & \multicolumn{2}{c|}{$\begin{array}{c}\text { Pacientai, } \\
\text { sergantys sifiliu }\end{array}$} \\
\cline { 2 - 3 } & N & proc. \\
\hline Papulès & 364 & 55 \\
Erozijos & 254 & 39 \\
Kietasis šankeris & 220 & 33 \\
Rozeolès & 181 & 27 \\
Ploǩ̌čiosios kondilomos & 103 & 16 \\
Dėmės & 84 & 13 \\
Opos & 54 & 8 \\
Pustulès, plokštelès, & 43 & 6 \\
mazgai & & \\
\hline
\end{tabular}

(DVC - 19 proc. (76), RKL - 48 proc. (90) $(\mathrm{p}<0,001)$.

TPHA reakcija daugumai pacientų (64 proc. (793) buvo stipriai teigiama (4+), 1,2 proc. (15) - neigiama. 44 proc. (546) pacientu atlikta imunofermentinè reakcija, 1 proc. (12) ji buvo neigiama. Tamsaus lauko mikroskopija sifilio diagnostikai naudota 19 proc. (151) DVC ir 41 proc. (186) RKL pacientų $(\mathrm{p}<0,001)$. Ištyrimas dèl ŽIV antikūnų atliktas 61 proc. (485) DVC ir tik 10 proc. (47) RKL pacientu $(p<0,001)$, ŽIV infekcija nustatyta atitinkamai 3 ir 2 pacientams. Metų eigoje ŽIV tyrimų dažnis didèja, 2013 m. DVC dèl ŽIV ištirta 86 proc. (24), 2014 m. - 96 proc. (21) sifilio pacientų. 31 proc. (380) pacientų (40 proc. (245) moteru ir 21 proc. $(135)$ vyrų $(\mathrm{p}<0,001)$ nustatyta gretutine patologija. Iš lytiniu keliu perduodamų infekcijų, moterims dažniausiai nustatyta trichomonozè (13 proc. (80), bakterinè vaginozè $(8,2$ proc. (50) ir kandidamikozè $(6,3$ proc. (38). Vyrams iš lytiškai plintančių infekcijų dažniausiai nustatyta trichomonozė ( 3,6 proc. (23), iš infekcinių ligų plaučiu tuberkuliozè $(4,4$ proc. (28), iš sisteminių - psichinès ligos (3,5 proc. (22). Detali gretutinių susirgimų analizé pateikta 3 lentelèje.

37 proc. (462) pacientu gydyti ilgo veikimo benzatino benzilpenicilinu, vidutiniškai skiriant 3 injekcijas po 2,4 $\mathrm{mln}$. VV/sav. (suminė dozė: 7,2 $\pm 2 \mathrm{mln}$. VV). Iš jų 30 proc. (140) buvo išsiųsti ambulatoriniam gydymui ir kontrolei pagal gyvenamają vietą, 16 proc. (76) pacientu neatvyko gydymo kontrolès, o iš 53 proc. (246) pacientų, grịžusiu gydymo kontrolei, 62 proc. gydymas laikytas efektyviu. Antro pasirinkimo vaistu - doksiciklinu - gydyta 7 proc. (90) pacientu, skiriant $200 \mathrm{mg}$ per dieną, vidutiniškai 23

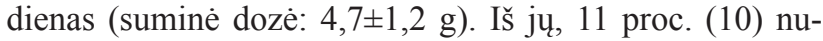
kreipta ambulatoriniam gydymui, 30 proc. (27) - negrižo, o iš 59 proc. (53) grižusių - 75 proc. (40) gydymas laikytas sèkmingu. 11 proc. (139) pacientų gydyta benzilpenicilinu, 7 proc. (89) - prokainpenicilinu, 29 proc. (359) pacientu gydyti vaistų deriniu, 9 proc. (106) - išsiųsti ambulatoriam gydymui į kitą įstaigą be aiškių gydymo rekomendacijų. Gydymo efektyvumas tarp skirtų vaistų reikšmingai nesiskyre ( $p=0,092) .6$ pav. pateikiama susisteminta informacija apie sifilio gydymą, jo efektyvumą bei pacientų kontrolę. Gydymo efektyvumas skaičiuotas tik tiems pacientams, kurie grįžo pakartotiniam RPR tyrimui. Gydymas laikytas veiksmingu, jei RPR titras 12 mèn. laikotarpiu sumažèjo keturis kartus. Greičiausiai efektas buvo pasiekiamas doksicikliną vartojusiųu grupejje (4,8 mèn.), tačiau jis reikšmingai nesiskyrè nuo kitų vaistų. Laikas iki teigiamo serologinio atsako, t.y. RPR titro sumažejjimo keturis kartus, pateikiamas 4 lentelèje. Gydymas neefektyvus buvo 7,3 proc. (91) pacientų (7 proc. (55) DVC vs. 8 proc. (36) RKL $(\mathrm{p}=0,951)$. Gydymo kursas kartotas 2,5 proc. (31) pacientu. 
2 lentelè. Pacientų, kuriems diagnozuotas sifilis (DVC ir RKL), bèrimo elementų lokalizacijos (procentinè išraiška). V - vyrai, $\mathrm{M}$ - moterys.

\begin{tabular}{|c|c|c|c|c|c|c|c|c|c|c|c|c|c|c|c|c|}
\hline $\begin{array}{r}\text { Bèrimo } \\
\text { elementai }\end{array}$ & \multicolumn{2}{|c|}{ 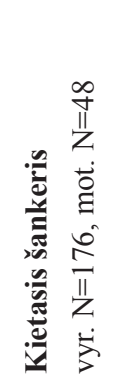 } & \multicolumn{2}{|c|}{ 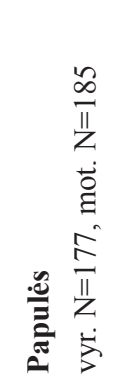 } & \multicolumn{2}{|c|}{ 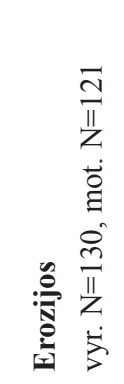 } & \multicolumn{2}{|c|}{ 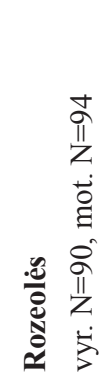 } & \multicolumn{2}{|c|}{ 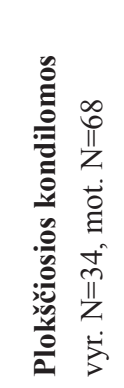 } & \multicolumn{2}{|c|}{ 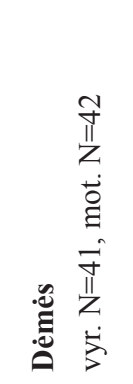 } & \multicolumn{2}{|c|}{ 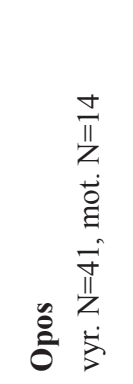 } & \multicolumn{2}{|c|}{ 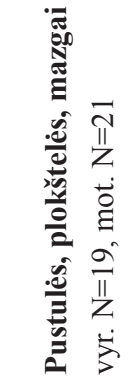 } \\
\hline \multicolumn{17}{|c|}{ Vyrų lytiniai organai } \\
\hline Varpos galva & \multicolumn{2}{|c|}{26} & \multicolumn{2}{|c|}{3} & \multicolumn{2}{|c|}{29} & \multirow{2}{*}{\multicolumn{2}{|c|}{ - }} & \multicolumn{2}{|c|}{ 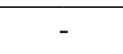 } & & \multicolumn{2}{|c|}{17} & \multicolumn{2}{|c|}{5} \\
\hline Apyvarpė & \multicolumn{2}{|c|}{49} & \multicolumn{2}{|c|}{17} & \multicolumn{2}{|c|}{48} & & & \multicolumn{2}{|c|}{12} & & \multicolumn{2}{|c|}{29} & \multicolumn{2}{|c|}{11} \\
\hline Varpos kūnas & \multicolumn{2}{|c|}{21} & \multicolumn{2}{|c|}{18} & \multicolumn{2}{|c|}{16} & & - & & & & & & & & 5 \\
\hline Sëklidès & & & & 0 & & & & - & & & & & & & & 5 \\
\hline & & & & & & teru & & i & & & & & & & & \\
\hline Didžiosios lyt. lūpos & 6 & & & 9 & & & & 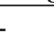 & & & & & & & & 42 \\
\hline Mažosios lyt. lūpos & 2 & & & 1 & & & & - & & & & & & & & - \\
\hline Makšties gleivinė & ( & & & - & & & & 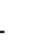 & & & & & & & & - \\
\hline & & & & & & nog & ital & è $\mathbf{s r}$ & & & & & & & & \\
\hline & $\mathbf{V}$ & M & $\mathbf{V}$ & $\mathbf{M}$ & $\mathrm{V}$ & $\mathbf{M}$ & $\mathbf{V}$ & $\mathbf{M}$ & $\mathbf{V}$ & M & $\mathbf{V}$ & M & $\mathbf{V}$ & M & $\mathbf{V}$ & $\mathbf{M}$ \\
\hline Išangè & 0,5 & 4 & 14 & 16 & 18 & 18 & - & - & 79 & 71 & - & - & 2 & 29 & 5 & - \\
\hline Tarpvietė & - & 1 & 6 & 6 & 5 & 2 & - & 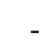 & 6 & 18 & - & - & - & - & 5 & - \\
\hline Kirkšnys & 0,5 & - & 9 & 15 & 3 & 1 & - & - & 6 & 7 & - & - & - & - & - & - \\
\hline & & & & & & & $10 \mathrm{~S}$ & & & & & & & & & \\
\hline Galvos plauk. dalis & - & - & 8 & 3 & 3 & 4 & - & - & - & - & - & - & - & - & 5 & 14 \\
\hline Veidas & - & - & 5 & 3 & 2 & 2 & 2 & 4 & - & - & - & - & - & - & 5 & 10 \\
\hline Lūpos & 1 & - & 2 & 2 & 11 & 15 & - & - & - & - & - & - & 15 & 29 & - & - \\
\hline Burnos gleivinè & 1 & - & 1 & 2 & 8 & 8 & - & - & - & - & - & - & 12 & 14 & - & 5 \\
\hline Liemuo & - & - & 36 & 34 & - & - & 96 & 94 & - & - & 88 & 76 & - & - & 47 & 19 \\
\hline Rankos & - & - & 10 & 11 & - & - & 12 & 15 & - & - & 5 & 14 & - & - & 5 & 5 \\
\hline Delnai & - & - & 28 & 29 & - & - & 4 & 10 & - & - & 5 & 12 & - & - & - & 5 \\
\hline Kojos & - & - & 7 & 9 & - & - & 11 & 21 & - & - & 7 & 14 & 17 & 7 & - & 5 \\
\hline Padai & - & - & 39 & 35 & - & - & 8 & 10 & - & - & 7 & 21 & - & - & - & - \\
\hline
\end{tabular}

Gydymo kontrolès iš viso neatvyko 13 proc. visų pacientų (17 proc. (138) DVC ir 5 proc. (22) RKL (p<0,001). Iš tų pacientų, kuriu stebejjimas po gydymo buvo vykdomas DVC (400) ir RKL (189), keturis ir daugiau kartų atvyko atitinkamai 30 proc. (120) ir 38 proc. (71) pacientų. Telefonu buvo susisiekta su bandomaja 10 pacientų grupe, neatvykusių gydymo kontrolès ị DVC: 5 tikrinosi kitose įstaigose, 2 manè, kad nereikia tikrintis ir 3 pacientai atvyko kontroliniam tyrimui per 3 mèn. nuo skambučio.

\section{Diskusija}

Per 15 m. Lietuvoje užregistruoti 6354 sifilio atvejai [8], taigi RKL ir DVC diagnozuoti atvejai kartu sudare 24 proc. visų užregistruotų sifilio atvejų Lietuvoje $(13,4$ proc. DVC ir 10,5 proc. RKL). Sifilio atvejų skaičius 2000-2004 m. stipriai sumažèjo ir nuo $2005 \mathrm{~m}$. išlieka gana stabilus. Tai būtų galima sieti su privačios medicinos išpopuliarejimu bei apskaitos griežtumo sumažèjimu. Privačios medicinos įstaigos atsakingoms institucijoms dažnai nepraneša apie diagnozuotus sifilio atvejus. Beveik vienodas pasiskirstymas tarp lyčių dominuoja ir kitose Rytų Europos šalyse. Vakarų Europoje vyrai serga vidutiniškai 4 kartus dažniau, nei moterys ir beveik pusè susirgimų nustatoma tarp homoseksualių vyrų [10]. DVC ir RKL pacientų lytinè orienta- 
3 lentelė. DVC ir RKL sifiliu sergančiu pacientų lydinčios ligos ir sukèlèjai

\begin{tabular}{|c|c|c|c|c|}
\hline \multirow{2}{*}{$\begin{array}{l}\text { Sergančiųjų sifiliu } \\
\text { gretutinès ligos }\end{array}$} & \multicolumn{2}{|c|}{ Moterys } & \multicolumn{2}{|c|}{ Vyrai } \\
\hline & $\mathbf{N}$ & proc. & $\mathbf{N}$ & proc. \\
\hline \multicolumn{5}{|c|}{ Lytiniu keliu plintačios ligos } \\
\hline Candida albicans infekcija & 38 & 6,3 & 11 & 1,7 \\
\hline Bakterinè vaginozè & 50 & 8,2 & - & - \\
\hline Trichomonozė & 80 & 13 & 23 & 3,6 \\
\hline Gonorejja & 3 & 0,5 & 8 & 1,3 \\
\hline Chlamidiozè & 1 & 0,2 & 2 & 0,3 \\
\hline M. genitalium infekcija & - & - & 1 & 0,2 \\
\hline U. urealyticum infekcija & 7 & 1 & 4 & 0,6 \\
\hline Hepatitas C & 3 & 0,5 & 1 & 0,2 \\
\hline Hepatitas B & - & - & 3 & 0,5 \\
\hline Herpes simplex 2 infekcija & 2 & 0,3 & 2 & 0,3 \\
\hline Herpes simplex 1 infekcija & 2 & 0,3 & - & - \\
\hline ŽIV & 2 & 0,3 & 3 & 0,5 \\
\hline Kondilomos & 4 & 0,7 & 3 & 0,5 \\
\hline \multicolumn{5}{|c|}{ Kitos infekcinès ligos } \\
\hline Plaučių tuberkuliozė & 11 & 2 & 28 & 4,4 \\
\hline Niežai & 8 & 1,3 & 11 & 1,7 \\
\hline Pedikuliozè & 10 & 1,6 & 5 & 0,8 \\
\hline Laimo liga & 5 & 0,8 & 1 & 0,2 \\
\hline \multicolumn{5}{|c|}{ Sisteminès ligos } \\
\hline Psichinė liga & 14 & 2,3 & 22 & 3,5 \\
\hline Psoriazė & 5 & 0,8 & 9 & 1,4 \\
\hline Neoplazija & 7 & 1 & - & - \\
\hline
\end{tabular}

cija nebuvo dokumentuojama. Kadangi ištirta mažiau nei pusė sirgusiujų lytinių kontaktų, tai potencialiai skatina infekcijos plitimą [5]. Sifiliu dažniau sirgo mieste gyvenantys žmonès, be to, dirbantys vyrai sifiliu sirgo dažniau nei bedarbiai - tai galima būtų sieti su labiau prieinamomis komercinėmis sekso paslaugomis [12]. Kadangi trečdaliui moterų sifilis nustatytas atsitiktinai, nèštumo profilaktinių tyrimų metu, i DVC moterys dažniausiai atvykdavo su gydytojo akušerio-ginekologo siuntimu, nes tai yra tretinio lygio ịstaiga, galinti teikti specializuotą pagalbą něščiosioms. Be to, tai patvirtina faktą, jog daugumai moterų kietasis šankeris užgyja nepastebètas [1]. Taip pat, galima teigti, jog néščiujų skriningas Lietuvoje yra veiksmingas, kadangi nuo $2009 \mathrm{~m}$. RKL ir DVC nebuvo igimto sifilio atvejų.

Pirminis sifilis nustatytas tik mažai daliai pacientų. Vyrams jis buvo diagnozuojamas keturis kartus dažniau, nes kietasis šankeris, nors įprastai neskausmingas ir savaime praei- nantis, tačiau pasireiškęs varpos srityje jis dažniausiai sukelia simptomatiką, dėl to vyrus dažniau priverčia kreiptis ị gydytojus $[1,4,13]$. Nustatytos dažniausios kietojo šankerio lokalizacijos atitinka literatūroje aprašytas, tačiau reikètų nepamiršti, kad jis ne visada būna tik lytinių organų srityje $[1,14]$. Antrinio sifilio metu pasireiškè visi galimi bèrimo elementai. Papulių dažniausiai ieškoti derètų liemens, delnų ir padų odoje; erozijų - lyties organuose, tarpvieteje bei burnos gleivinejje; plokščiujų kondilomu - anogenitalinėje srityje. Kartu su bèrimais, daugumai pacientu pasireiškè limfadenopatija, o kas ketvirtam antriniu sifiliu sirgusiam pacientui nustatyta alopecija, tonzilitas ar išskyrų iš lytinių organų pagausejjimas.

Tamsaus lauko mikroskopija ypač naudinga greitai pirminio ir antrinio sifilio, su išryškejjusiais bèrimo elementais, diagnostikai. Jos pagalba sifili galima diagnozuoti dar prieš antikūnams kraujyje susiformuojant $[1,15]$. DVC ji taikyta tik penktadaliui pacientų, nes nuo $2007 \mathrm{~m}$. nebèra taikoma dèl techninių apribojimų. RPR (angl. Rapid plasma reagin, greitas plazmos reaginu testas) yra netreponeminis kiekybinis tyrimas, naudingas ligos aktyvumo ir gydymo efektyvumo vertinimui. Abiejuose centruose dèl ilgametès patirties, patogumo ir pigumo jis dažniausiai naudojamas ir pacientų skriningui. RPR tyrimas teigiamas tampa praejus 10-15 d. nuo kietojo šankerio atsiradimo [2]. Aukščiausi RPR titrai nustatyti antriniu sifiliu sergantiems pacientams. 6 proc. pacientų šis tyrimas buvo klaidingai neigiamas (daliai jų - dèl prozono fenomeno), todèl sifilio diagnostikoje negalima apsiriboti tik šiuo tyrimu. Kokybiniai treponeminiai testai (šiuo atveju - TPHA, Treponema pallidum hemagliutinacijos testas, ir IFA - imunofermentinis tyrimas) naudojami sifilio diagnozei patvirtinti. TPHA tyrimas pasižymi dideliu jautrumu ir specifiškumu [16,17], tačiau ir jis 1 proc. pacientų buvo klaidingai neigiamas, nes reaktyvus tampa praejjus 1-2 sav. nuo kietojo šankerio

4 lentelè. DVC ir RKL sifiliu sergančių pacientų laikas iki teigiamo serologinio atsako * lenteleje paminéti vaistai buvo derinami tarpusavyje

\begin{tabular}{|c|c|c|c|c|}
\hline Vaistas & $\begin{array}{l}\text { Pacientų } \\
\text { skaičius, } \\
\text { N }\end{array}$ & $\begin{array}{l}\text { Suminė dozė, } \\
\text { vidurkis } \pm \text { SD }\end{array}$ & $\begin{array}{l}\text { Trukmė iki teigiamo } \\
\text { serologinio atsako, } \\
\text { mèn. [95 proc. } \mathrm{PI}]\end{array}$ & $\begin{array}{l}\text { ANOVA P } \\
\text { reikšmė }\end{array}$ \\
\hline $\begin{array}{l}\text { Benzatino } \\
\text { benzilpenicilinas }\end{array}$ & 159 & $7,2 \pm 2 \mathrm{mln} . \mathrm{VV}$ & $5,09[3,94 ; 6,25]$ & \\
\hline Doksiciklinas & 41 & $4,7 \pm 1,2 \mathrm{~g}$ & $4,85[2,86 ; 6,85]$ & \\
\hline Benzilpenicilinas & 45 & $118 \pm 123 \mathrm{mln} . \mathrm{VV}$ & $5,67[3,73 ; 7,60]$ & 0.264 \\
\hline Prokainpenicilinas & 24 & $16,8 \pm 3,8 \mathrm{mln} . \mathrm{VV}$ & $8,54[4,21 ; 12,87]$ & \\
\hline Vaistų derinys* & 133 & - & $5,52[4,39 ; 6,65]$ & \\
\hline Bendras vidurkis & 402 & - & $5,48[4,78 ; 6,18]$ & \\
\hline
\end{tabular}




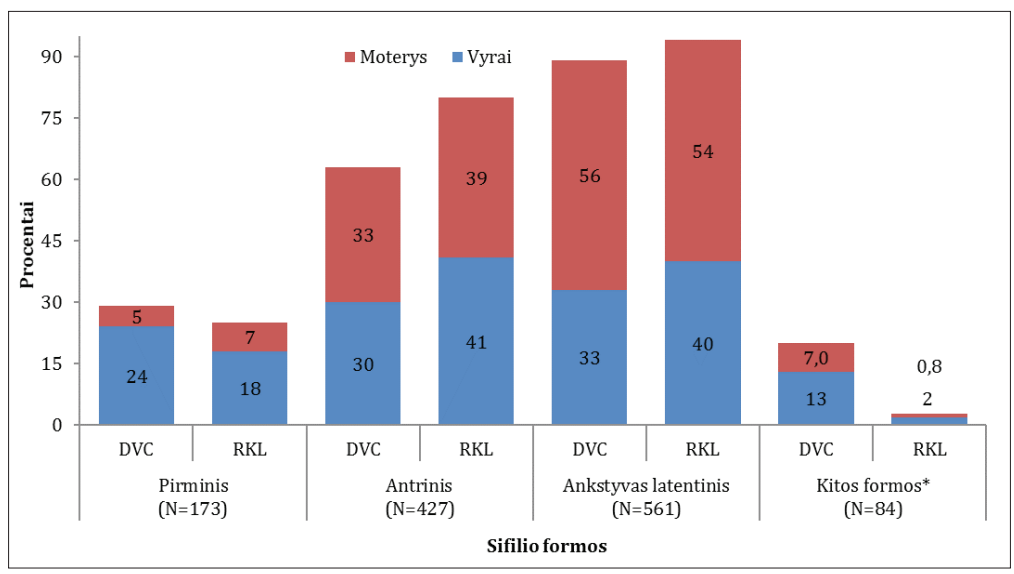

1 pav. Sifilio formų pasiskirstymas tarp lyčių Dermatovenerologijos centre (DVC) ir Respublikinèje Klaipèdos ligoninèje (RKL)

*kitos formos: vélyvas latentinis, igimtas, tretinis ir neurosifilis.
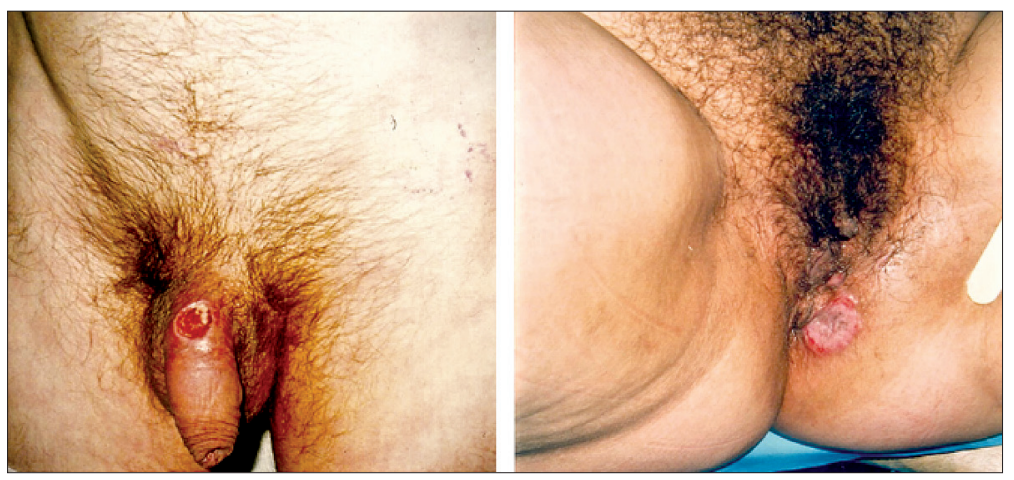

2 pav. Kietasis šankeris pirminiu sifiliu sergantiems pacientams. Kairejje $-33 \mathrm{~m}$. pacientas, šankeris varpos kūne, dešinèje $-25 \mathrm{~m}$. pacientè, šankeris tarpvietèje.
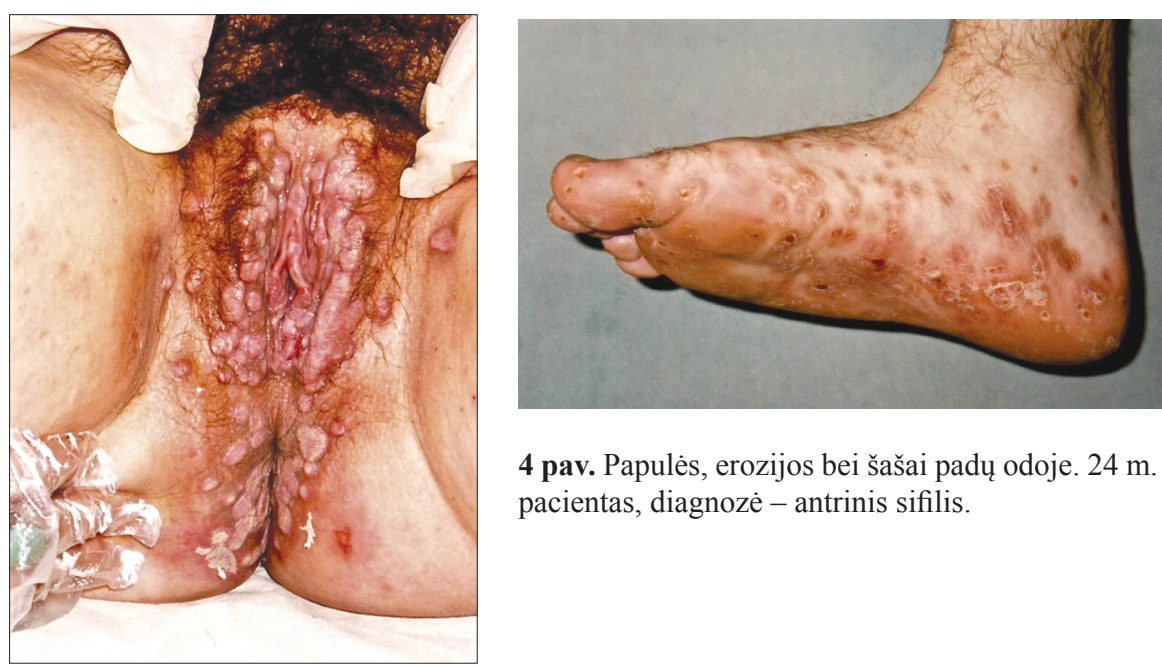

4 pav. Papulès, erozijos bei šašai padų odoje. $24 \mathrm{~m}$. pacientas, diagnozè - antrinis sifilis.

3 pav. Plokščiosios kondilomos anogenitalinejje srityje, nustatytos $16 \mathrm{~m}$. néščiai pacientei, kuriai diagnozuotas antrinis sifilis. susiformavimo [2]. Papildomai beveik pusei pacientu atliktas imunofermentinis treponemų tyrimas, kuris yra pilnai automatizuotas, tačiau sąlyginai brangesnis [2,5]. Pastarieji du tyrimai nerekomenduojami gydymo efektyvumo vertinimui, kadangi gali išlikti teigiami visą gyvenimą [2]. Tačiau $2014 \mathrm{~m}$. Europos sifilio gydymo gairèse juos vis dažniau siūloma naudoti sifilio skriningui [5], kadangi jie pasižymi ypač dideliu jautrumu [18].

Visiems pacientams, kuriems diagnozuotas sifilis, rekomenduojama atlikti ŽIV antikūnų testą, nes tikimybė užsikrèsti padidèja 2-5 kartus $[11,19]$, tačiau DVC jis atliktas tik kiek daugiau nei pusei, o RKL - vos dešimtadaliui pacientų, dèl to ŽIV infekcija diagnozuota 5 pacientams. DVC prieš keletą metų įdiegus ŽIV express diagnostiką, pacientų ištyrimas arteja prie 100 proc. Be to, rekomenduojamas nuodugnus ir visapusiškas kiekvieno paciento ištyrimas, kadangi sergantieji sifiliu turi didesnę riziką užsikrèsti ir kitomis infekcinèmis ligomis [11]. DVC ir RKL trečdaliui pacientų nustatyta gretutinè patologija - iš lytiniu keliu plintančių ligų dažniausiai diagnozuota trichomonozè, iš kitų infekcinių ligų - plaučių tuberkuliozé, iš sisteminių - psichinès ligos (3 lentelè).

Dauguma pacientu buvo gydomi pirmo pasirinkimo vaistu $[5,11]$ - benzatino benzilpenicilinu. Didžiajai daliai jų buvo skirtos trys injekcijos - maksimalus rekomenduojamas gydymo kursas. Doksiciklinas, kaip alternatyva, skirtas dešimtadaliui pacientų, taip pat skiriant maksimalų kursą (vid. 23 dienas) [5]. Antroje vietoje buvo vaistų derinys, pavyzdžiui, 14 dienų benzilpenicilino kursas ir vienkartine benzatino benzilpenicilino injekcija, 4 dienų doksiciklino kursas ir 3 benzatino benzilpenicilino injekcijos. Tokie vaistų deriniai $2014 \mathrm{~m}$. Europos sifilio gydymo gairèse nerekomenduojami, ir, kaip matyti iš gautų rezultatų (4 lentelè), geresniu atsaku i gydymą nepasižymi. Be to, 9 proc. (106) pacientų buvo išsiųsti ambulatoriniam gydymui ị kitas įstaigas 


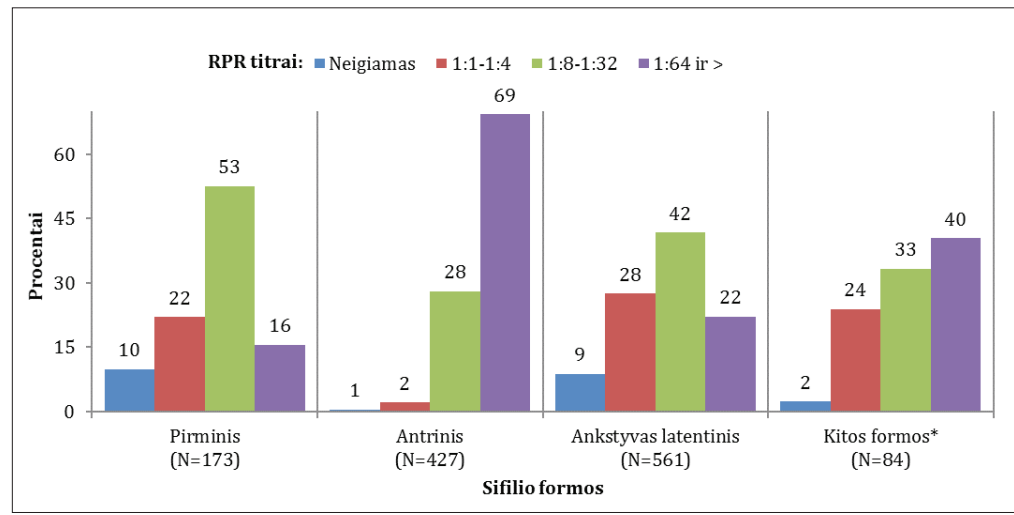

5 pav. Ryšys tarp pradinio RPR titro ir sifilio formų DVC ir RKL *kitos formos: velyvas latentinis, igimtas, tretinis ir neurosifilis.

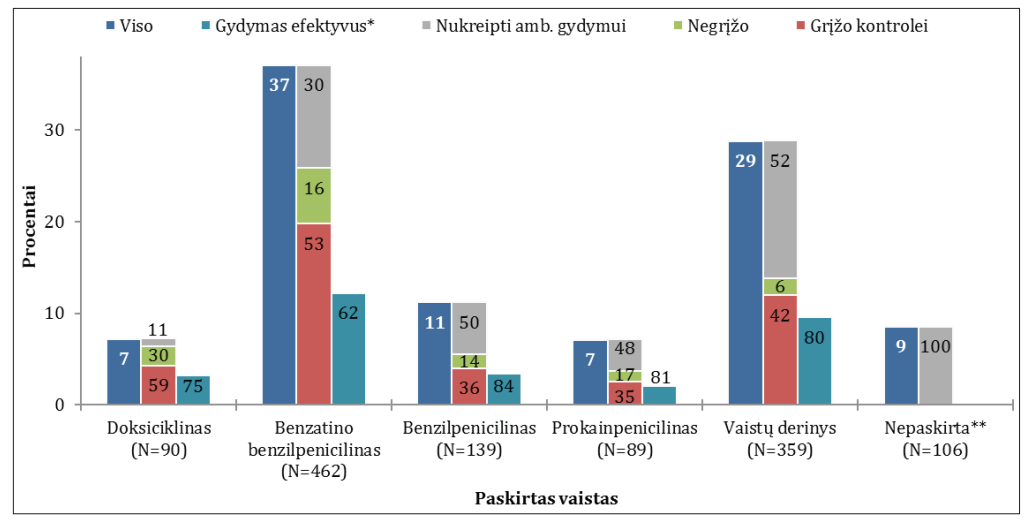

6 pav. Sifilio gydymas, jo efektyvumas ir pacientų kontrolè DVC ir RKL * gydymo efektyvumas skaičiuotas pacientams, kurie grižo pakartotiniam RPR tyrimui.

** šie pacientai be gydymo rekomendaciju buvo išsiusti ambulatoriniam gydymui vietinèse klinikose

be dokumentuotų gydymo rekomendacijų.

Gydymo efektyvumo vertinimui RPR tyrimą rekomenduojama kartoti praejus 1, 3, 6 ir 12 ménesių po gydymo. Gydymas laikomas efektyviu, jei 12 mèn. laikotarpiu RPR titras sumažeja 4 kartus $[5,11]$. Greičiausiai teigiamas serologinis atsakas buvo pasiekiamas doksiciklino ir benzatino benzilpenicilino grupėse, tačiau reikšmingai nesiskyrè. Kadangi rekomenduojamus 4 ir daugiau kartu kontroliniams RPR tyrimams atvyko tik trečdalis pacientu, sunku vertinti realų vaistų efektyvumą. Gydymas neefektyviu laikytas 7 proc. pacientų, tačiau diskutuojama, ar verta tokiu atveju kartoti gydymo kursą [20], nors tiems pacientams rekomenduojama atlikti lumbalinę punkciją ir ištirti likvorą dèl neurosifilio [11]. Be to, didžioji dalis šių pacientų sirgo vèlyvuoju sifiliu, po kurio dauguma pacientu nepasiekia pageidaujamo RPR titro sumažèjimo [5]. I DVC kontrolès iš viso neatvyko trigubai daugiau pacientų, nei į RKL, kur neatvyktantys pacientai yra kviečiami telefonu. Pasiteisi- nus bandomajam pacientų kvietimui atvykti i DVC, planuojama plačiau pradèti taikyti šią praktiką, pasitelkiant ir kitas informacijos priemones.

\section{Išvados}

Nors atvejų skaičius Lietuvoje per paskutinius 15 metu gerokai sumažèjo, sergamumas sifiliu išlieka didelis. Šis tyrimas apėmè ketvirtadali Lietuvos sifilio pacientų. Pasiskirstymas tarp lyčiu buvo beveik vienodas, tačiau vyrai buvo vidutiniškai 5 metais vyresni už moteris. Abiejuose centruose dažniausiai diagnozuotas ankstyvas latentinis ir antrinis sifilis, todèl bèrimai pasireiškẻ tik pusei pacientų. Mažiau nei pusè pacientų ištirta dèl ŽIV. Gydymas doksiciklinu ir penicilinais yra vienodai efektyvūs, teigiamas serologinis atsakas pasiekiamas vidutiniškai po 6 mèn. Gydymo kontrolès atvyksta du trečdaliai pacientų, tačiau tik trečdaliui atliekamas rekomenduojamas RPR tyrimu skaičius.

\section{Literatūra}

1. Kinghorn GR. Syphilis and Bacterial Sexually Transmitted Infections. Rook's Textbook of Dermatology, 8th ed. Wiley-Blackwell 2010;34:1-24.

2. Unemo M, Ballard R, Ison C, Lewis D, Ndowa F, Peeling R. Laboratory diagnosis of sexually transmitted infections, including human immunodeficiency virus. Geneva, Switzerland, WHO 2013;107-29.

3. Kent ME, Romanelli F. Reexamining Syphilis: An Update on Epidemiology, Clinical Manifestations, and Management. Ann Pharmacother 2008;42(2):226-36.

4. Hope-Rapp E, Anyfantakis V, Fouéré S, Bonhomme P, Louison JB, de Marsac TT, et al. Etiology of genital ulcer disease. Sex Transm Dis 2010;37(3):153-8.

5. Janier M, Hegyi V, Dupin N, Unemo M, Tiplica GS, Potočnik M. et al. 2014 European guideline on the management of syphilis. J Eur Acad Dermatol Venereol 2014;28(12):1581-93.

6. World Health Organization. Guidelines for the management of sexually transmitted infections. Geneva, Switzerland, WHO, 2003;91.

7. Rowley J, Toskin I, Ndowa F, World Health Organization, Reproductive Health and Research. Global incidence and prevalence of selected curable sexually transmitted infections - 2008. Geneva, Switzerland, WHO 2012; 2.

8. Higienos instituto Sveikatos informacijos centras. http://sic. hi.lt (2015 04 11) 
9. Čaplinskienė I., Šimkūnaitė-Zažeckè A., Andrulaitytė G. Užsikrètusiųjų lytiškai plintančiomis infekcijomis ir žmogaus imunodeficito virusu epidemiologinès situacijos 2013 m. apžvalga už ULAC, 2014; 9-14.

10. European Centre for Disease Prevention and Control. Annual Epidemiological Report 2013. Stockholm, ECDC, 2013;55-9.

11. Workowski KA, Berman S, Centers for Disease Control and Prevention (CDC). Sexually transmitted diseases treatment guidelines. MMWR Recomm Rep Morb Mortal Wkly. CDC, 2010;59(RR-12):1-110.

12. Kang D, Liao M, Jiang Z, Zhang X, Mao W, Zhang N. et al. Commercial sex venues, syphilis and methamphetamine use among female sex workers. AIDS Care 2011;23(1):26-36.

13. Dunlop EMC. Some aspects of infectious Syphilis today. Public Health 1964;78:259-67.

14. Mindel A, Tovey SJ, Timmins DJ, Williams P. Primary and secondary syphilis, 20 years' experience. Genitourin Med 1989;65(1):1-3.

15. Wheeler HL, Agarwal S, Goh BT. Dark ground microscopy and treponemal serological tests in the diagnosis of early syphilis. Sex Transm Infect 2004;80(5):411-4.

16. O’Neill P, Warner RW, Nicol CS. Treponema pallidum haemagglutination assay in the routine serodiagnosis of treponemal disease. Br J Vener Dis 1973;49(5):427-31.

17. Robertson DH, McMillan A. Clinical value of the Treponema pallidum haemagglutination test. Br J Vener Dis 1975;51(2):7982.

18. Tipple C, Taylor GP. Syphilis testing, typing, and treatment follow-up: a new era for an old disease. Curr Opin Infect Dis 2015;28(1):53-60.

19. Lynn W, Lightman S. Syphilis and HIV: a dangerous combination. Lancet Infect Dis 2004;4(7):456-66.

20. Ren R-X, Wang L-N, Zheng H-Y, Li J. No improvement in serological response among serofast latent patients retreated with benzathine penicillin. Int J STD AIDS 2015;31-6.

\section{YEARS' EXPERIENCE OF SYPHILIS' DIAGNOSTICS AND TREATMENT IN TWO LITHUANIAN CENTRES}

T. Raudonis, T. Orlovskytė, A. Šumila, A. Kajutytė, G.S. Lapinskaitė, M. Bylaitė-Bučinskienè

Key words: syphilis, chancre, RPR, TPHA, HIV, benzathine benzylpenicillin, doxycycline.

Summary

Syphilis is a disease of systemic nature which is characterised by varied clinical manifestations, therefore physicians of most specialities may encounter it. Also, Lithuania has one of the highest incidence rates of syphilis in the European Union. In this paper we present data collected over a period of 15 years in two Lithuanian dermatovenereology centres - Vilnius University
Dermatovenereology centre (DVC) and Department of Skin and Venereal Diseases at Republic Klaipeda Hospital (RKL).

Objectives: To determine the annual rate of syphilis' cases during the 15 year period, the frequency of different stages, gender differences, clinical morphology, diagnostic measures and treatment efficacy of syphilis.

Material and methods: We conducted a retrospective analysis consisting of 1245 patient medical records: 793 patients from DVC and 452 from RKL. Data was processed with SPSS, ANOVA test was used for means, the significance of other data was assessed with either Fisher's or Chi-square tests.

Results: 691 case was registered in DVC and RKL during 2000-2003, and 554 cases - during 2004-2014. 49\% (610) of patients were female, their age average $-29.5 \pm 11.3$ years, male age $-34.3 \pm 12.3$ years. $(\mathrm{p}<0.001)$. Among patients living in the city, males were more frequently employed $(55 \%$ (222) than females (48\% (172) $(\mathrm{p}=0.050)$. Primary syphilis was diagnosed for $14 \%$ (173) of patients, secondary - 34\% (427), early latent - 45\% (561). $53 \%$ (660) of patients presented with skin lesions on examination. Papules were observed in 55\% (364) of patients, erosions $-39 \%$ (254), chancre $-33 \%$ (220). Primary and early latent syphilis were associated with lower RPR titres, whereas secondary syphilis - with exceptionally high titres (69\% (296). 6\% (70) had a negative RPR test. Four or more RPR tests were carried out on $19 \%$ (76) of DVC and $48 \%$ (90) of RKL patients $(\mathrm{p}<0.001)$. Dark-field microscopy was used for $19 \%$ (151) of DVC and 41\% (186) of RKL patients $(\mathrm{p}<0.001)$. HIV test was performed for $61 \%(485)$ of DVC and $10 \%$ (47) of RKL patients ( $<<0.001) .37 \%$ (462) of patients were treated with benzathine benzylpenicillin, on average 3 injections of $2.4 \mathrm{mU}$ per week. Doxycycline was prescribed for 7\% (90) of patients, on average $200 \mathrm{mg}$ daily for 23 days (cumulative dose of $4.7 \pm 1.2$ g.). Time to serological response varied insignificantly (5.09 [3.94; 6.25] vs. 4.85 [2.86; 6.85] months). $7.3 \%$ (91) of patients experienced treatment failure $(7 \%(55)$ in DVC vs. $8 \%$ (36) in RKL ( $\mathrm{p}=0.951)$.

Conclusions: Even though the number of registered syphilis' cases in DVC and RKL has decreased almost 10-fold over the course of 15 years, the incidence rate remains among the highest in the European Union. Early latent and secondary were the two most diagnosed stages of syphilis. The male to female ratio was close to 1 , though males were approximately 5 years older. Only half of the patients presented with lesions. Less than half of the patients were tested for HIV. Both doxycycline and benzathine benzylpeniciline were equally effective. Only one-third of patients had the recommended number of follow-up RPR tests done.

Correspondence to: tadasr@me.com

Gauta 2015-05-28 